\title{
Survival-Day @ Wiesbaden business school - evaluation of a short-term educational intervention to reduce work-associated health risks during nursing internships of students in health care economics
}

\author{
Reinhard Strametz ${ }^{1}$, Thomas Schneider ${ }^{2}$, Andreas Pitz ${ }^{3}$ and Matthias Raspe ${ }^{4^{*}}$ (D)
}

\begin{abstract}
Background: In 2013 RheinMain University launched its bachelor's degree program Health Care Economics requiring each student to participate in a mandatory two-month nursing internship. A preliminary risk assessment revealed serious risks for both students and patients and had to be addressed by appropriate measures such as mandatory systematic safety training for each student.

Methods: A short-term educational intervention named "Survival-Day" was designed to minimize risks related to nursing internships of students. This intervention consists of six 45-min-units with theoretical input ( 2 units) and hands-on training (4 units) imparting basic knowledge and skills in CPR, hand hygiene and handling of masks and protective gowns, prevention of needle stick injuries, fire protection and firefighting. Performance of CPR was assessed using computerized manikins. Acceptance, necessity and usability were assessed anonymously by standardized written questionnaires after completion of nursing internships.

Results: 462 students have completed the Survival-Day until January 2019. CPR performance showed acceptable adherence rates to guideline recommendations (mean 78.8\%, SD $\pm 22.6 \%$ ). The majority of students performed aseptic health care activities (66\%), treated patients with multi-resistant pathogens (62\%) and disposed sharp instruments such as blood-contaminated needles (76\%). According to students' self-reports about these hazardous activities, less than $50 \%$ of these students received adequate safety training at nursing facilities. However, no sentinel events such as needle stick injuries or students becoming second victim have been reported.

Conclusion: Our study reveals severe discrepancies between legal obligation of nursing facilities to ensure safety instructions for nursing interns and initial training as perceived by this group. Mandatory initial training before conduction of hazardous tasks was mainly covered by our short-term educational intervention (Survival-Day). Regarding responsibility for their students a preliminary safety instruction program like the Survival-Day should be considered for all educational institutions sending students to nursing internships unless mandatory and sufficient safety trainings for nursing interns can be guaranteed by nursing facilities.
\end{abstract}

Keywords: Nursing internships, Initial training, Hand hygiene, Needle stick injuries, Second victim

\footnotetext{
* Correspondence: matthias.raspe@charite.de

${ }^{4}$ Department of Internal Medicine, Infectious Diseases and Respiratory

Medicine, Charité - Universitätsmedizin Berlin, corporate member of Freie

Universität Berlin, Humboldt-Universität zu Berlin, and Berlin Institute of

Health, Charitéplatz 1, 10117 Berlin, Germany

Full list of author information is available at the end of the article
}

(c) The Author(s). 2019 Open Access This article is distributed under the terms of the Creative Commons Attribution 4.0 International License (http://creativecommons.org/licenses/by/4.0/), which permits unrestricted use, distribution, and reproduction in any medium, provided you give appropriate credit to the original author(s) and the source, provide a link to the Creative Commons license, and indicate if changes were made. The Creative Commons Public Domain Dedication waiver (http://creativecommons.org/publicdomain/zero/1.0/) applies to the data made available in this article, unless otherwise stated. 


\section{Background}

Since 2013 RheinMain University of Applied Sciences has offered a bachelor's program in Health Care Economics (BHCE). This includes a mandatory two-month nursing internship in order to gain detailed and realistic knowledge and understanding of patient care, regarded to be crucial for sustainable professional success. The RheinMain University has formal contracts with nursing facilities defining common aspects of nursing internships, which are not specific for the health care sector. Due to greatly varying standards and capacities in these nursing facilities regarding initial trainings for interns, a general contractual agreement ensuring standardized training by all nursing facilities is not realistic.

Because of this lack of adequate training nursing internships can be categorized as danger-prone activities with relevant risks for the safety of patients and students [1-8]. Furthermore, patient care is not exclusively provided by fully trained nursing staff in health care organizations often suffering from staff shortage. Therefore risks have to be assessed systematically in order to minimize them [9-13]. Based on a systematic risk assessment previously described [14], a short-term educational intervention named "Survival-Day" was created by the RheinMain University itself to minimize work-related risks for both patients and $\mathrm{BCHE}$ students during their two-month nursing internship.

Undoubtedly, infectious hazards belong to the most important dangers in the area of health care [15-24]. However, the present intervention did not only address these important issues, but also others including appropriate fire protection, behavior in case of fire, basic life support and prevention of needle stick injuries.

The Survival-Day was invented to close gaps in knowledge and skills in order to empower non-nursing BHCE students to safely fulfill assigned tasks during their mandatory nursing internship since we hypothesized

Table 1 Curriculum of the Survival-Day @ Wiesbaden Business School, each unit consists of 45 min

\begin{tabular}{|c|c|c|c|}
\hline Unit & Topic & Content & Learning Objective \\
\hline 1 & $\begin{array}{l}\text { Fire protection and fire-fighting } \\
\text { procedures (lecture) }\end{array}$ & $\begin{array}{l}\text { - Prevention of outbreaks and spreading of fire } \\
\text { - Securing of emergency exits and escape routes } \\
\text { - Performance of self-help measures } \\
\text { - Support of fire-fighters }\end{array}$ & $\begin{array}{l}\text { - Students know how to minimize risk for } \\
\text { outbreaks of fire by attending to fire } \\
\text { protection procedures }\end{array}$ \\
\hline 2 & $\begin{array}{l}\text { CPR algorithm In-hospital Basic } \\
\text { Life Support (lecture) }\end{array}$ & $\begin{array}{l}\text { - Basic principles of CPR } \\
\text { - ERC In-hospital BLS-algorithm } \\
\text { - Crew resource management principles to reduce } \\
\text { the risk of insufficient support during medical } \\
\text { emergencies }\end{array}$ & $\begin{array}{l}\text { - Students know about importance of } \\
\text { immediate response to patients with } \\
\text { suspected cardiac arrest and possible } \\
\text { tasks for them in case of such emergencies }\end{array}$ \\
\hline 3 & $\begin{array}{l}\text { CPR training } \\
\text { (hands-on training) } \\
\text { max. } 16 \text { students/group }\end{array}$ & $\begin{array}{l}\text { - Instruction how to use a bag valve mask } \\
\text { - Supervised free hands-on training with real time } \\
\text { feedback (Laerdal QCPR Anne Classroom Mode) in } \\
\text { teams of two students per manikin } \\
\text { - Five minutes drill for each student to perform in } \\
\text { hospital BLS in teams of two students per manikin }\end{array}$ & $\begin{array}{l}\text { - Students show how to perform in } \\
\text { hospital BLS to a CPR manikin for } 5 \text { min } \\
\text { at acceptable performance levels }\end{array}$ \\
\hline 4 & $\begin{array}{l}\text { Prevention of needle stick injuries } \\
\text { (hands-on training) } \\
\text { max. } 16 \text { students/group }\end{array}$ & $\begin{array}{l}\text { - Demonstration of blunt cannulas for preparing } \\
\text { intravenous medication } \\
\text { - Demonstration of sharp cannulas and drips incl. } \\
\text { Safeguard mechanisms } \\
\text { - Demonstration and hands-on training of each } \\
\text { student of secure handling and appropriate } \\
\text { disposal of sharp instruments } \\
\text { - Measures of post-exposure prophylaxis after } \\
\text { needle stick injuries to prevent HIV infection }\end{array}$ & $\begin{array}{l}\text { - Students know about risk of needle stick } \\
\text { injuries, risk-reducing strategies such as } \\
\text { safety cannulas and post-exposure } \\
\text { prophylaxis } \\
\text { - Students show how to safely dispose } \\
\text { needles in a sharps disposal container. }\end{array}$ \\
\hline 5 & $\begin{array}{l}\text { Firefighting procedure } \\
\text { (hands-on training) } \\
\text { max. } 16 \text { students/group }\end{array}$ & $\begin{array}{l}\text { - Demonstration of the safe use of a fire } \\
\text { extinguisher } \\
\text { - Hands-on training for each student to extinguish } \\
\text { a fire in a fire simulator }\end{array}$ & $\begin{array}{l}\text { - Students show how to safely use a } \\
\text { hand-held fire } \\
\text { extinguisher in a fire simulator }\end{array}$ \\
\hline 6 & $\begin{array}{l}\text { Prevention of nosocomial infections } \\
\text { (hands-on training) } \\
\text { max. } 16 \text { students/group }\end{array}$ & $\begin{array}{l}\text { - Short lecture of five moments of hand hygiene } \\
\text { (slides provided by German Clean Hands campaign) } \\
\text { - Demonstration of hand disinfection using disinfectant } \\
\text { solution with UV-indicator and UV black light. } \\
\text { - Hands-on training for each student of hand } \\
\text { disinfection using disinfectant solution with } \\
\text { UV-indicator and UV black light with individual } \\
\text { instant feedback } \\
\text { - Demonstration and hands-on training for each } \\
\text { student of appropriate use and disposal of } \\
\text { protective suits (gown, gloves, face mask, cap) }\end{array}$ & $\begin{array}{l}\text { - Students know about strategies and } \\
\text { equipment to reduce nosocomial } \\
\text { transmission of multi-resistant } \\
\text { pathogens } \\
\text { - Students show how to disinfect their } \\
\text { hands correctly } \\
\text { - Students show how to put on and } \\
\text { remove mask and protective gown } \\
\text { before and after contact with patients } \\
\text { having multi-resistant pathogens }\end{array}$ \\
\hline
\end{tabular}


that induction training at nursing facilities might be inadequate due to lack of time due to staff shortage. Results of acceptance, necessity and usability of this training program will be presented in this paper.

\section{Methods}

The intervention consists of six 45-min teaching units as shown in Table 1 divided into theoretical input and hands-on training in small groups of up to 16 students per group. All units were taught by specialized staff (e.g. paramedics, physicians and fire prevention officers). Quality of in-hospital basic life support (BLS) was assessed since July 2015 to ensure sufficient hands-on performance via computerized measurement of CPR skills for a 5-min in-hospital BLS scenario. Performance of in hospital-BLS was assessed using the algorithm software of QCPR manikins of Laerdal Medical Inc., Stavanger/Norway, based on recommendations of European Resuscitation Council (ERC) Guidelines 2010 [25]. Results are presented by percentage of compliance with ERC's BLS algorithm as calculated by QCPR software. Scores were collected in a completely anonymized fashion and used only for analysis if students agreed after informed consent.

Completion of learning objectives for firefighting, prevention of needle stick injuries, handling of protective gowns and masks and hand hygiene were assessed by teaching staff until sufficient performance was achieved during the intervention. Overall acceptance and recommendation rate were assessed for evaluation of the first event in January 2015 prior to nursing internships by using the German school grade system $(1=$ very good to $6=$ unsatisfactory). Acceptance of this short-term intervention and on-site instructions at nursing facilities were assessed. Therefore, all students who finished their nursing internship between July 2017 and September 2018 were asked to complete a standardized content-validated questionnaire also using the German school grade system.

All questionnaires were completely anonymized to ensure standards of data protection. Anonymized use of data for scientific reasons was declared in all questionnaires. Descriptive analysis was done using Microsoft Excel@ 2016.

\section{Results}

Since the initial intervention in January 2014 a total number of 462 non-nursing BHCE students have participated in this educational intervention, as shown in Table 2. No student was allowed to enter mandatory nursing internship without completion of the Wiesbaden Survival-Day.

Performance rates of in-hospital BLS showed an overall acceptable ERC BLS scores (mean 78.8\%, SD $\pm 22.6 \%$, $n=346)$ compared to similar educational interventions
Table 2 Numbers of health care economy students participating at the Survival-Day

\begin{tabular}{lll}
\hline Semester & $N=$ & female / male \\
\hline winter 2014 & 43 & $36 / 7$ \\
summer 2015 & 59 & $49 / 10$ \\
winter 2015 & 66 & $51 / 15$ \\
summer 2016 & 55 & $48 / 7$ \\
winter 2016 & 67 & $58 / 9$ \\
summer 2017 & 50 & $40 / 10$ \\
winter 2017 & 45 & $41 / 4$ \\
summer 2018 & 24 & $20 / 4$ \\
winter 2018 & 53 & $45 / 8$ \\
total & 462 & $388 / 74$ \\
\hline
\end{tabular}

[26, 27]. Learning objectives for all hands-on training sites were achieved by all participating students. No injuries or critical incidents were reported during any session of this short-term intervention.

Questionnaires for assessment of acceptance, necessity and usability were obtained from 104 BHCE students (response rate $87 \%$ ). Overall acceptance of the initial session in January 2015 was very good with a mean score of 1.9 (median 2) and recommendation rate of $94 \%$. Overall acceptance remained high after 2017 with mean grade 2.3 (median 2) compared to very mixed results for initial trainings at nursing facilities with mean grade 3.5 (median 3). Remarkably $24 \%$ of all students rated initial training at nursing sites to be deficient (grade 5) or unsatisfactory (grade 6). According to students' feedback concerning initial training at nursing facilities $54 \%$ of all students only received a rudimental initial training, while 30\% reported to have had no initial training all. Detailed aspects of nonnursing students' tasks at nursing sites as shown in Table 3 reveal severe discrepancies between assigned tasks and required initial training: The majority of BHCE students performed hazardous tasks like aseptic health care activities, treatment of patients with multi-resistant pathogens or disposal of sharp instruments. However more than 50\% of these non-nursing students performing these tasks did not receive any procedure specific safety training at nursing sites but had to refer to their knowledge and skills acquired at Survival-Day.

As presumed by our previous risk assessment tasks with extraordinary damage potential like detection of medical emergencies and assistance during CPR (9\% of all non-nursing students) as well as firefighting (one case at all) were quite rare but did occur.

Among all 402 non-nursing BHCE students successfully completing nursing internships until January 2019 no case of needle stick injury, second victim phenomenon or other serious harm of patients or students has been reported so far. 
Table 3 Students' tasks in relation to initial training at nursing facilities

\begin{tabular}{|c|c|c|c|c|c|}
\hline \multirow[t]{2}{*}{ Did you perform this kind of activity during your internship? } & \multirow[t]{2}{*}{$N=*$} & \multirow[t]{2}{*}{$\begin{array}{l}\text { no } \\
\text { n(\%) }\end{array}$} & \multirow[t]{2}{*}{$\begin{array}{l}\text { yes } \\
\text { n(\%) }\end{array}$} & \multicolumn{2}{|c|}{$\begin{array}{l}\text { Among all students who performed this task: } \\
\text { Did you receive a formal initial training at your } \\
\text { nursing site? }\end{array}$} \\
\hline & & & & yes $n(\%)$ & no n(\%) \\
\hline general nursing activities & 104 & $3(3)$ & $101(97)$ & $46(46)$ & $55(54)$ \\
\hline aseptic health care activities & 92 & $31(34)$ & $61(66)$ & $19(31)$ & $42(69)$ \\
\hline care of patients with multi-resistant pathogens & 92 & $35(38)$ & $57(62)$ & $30(53)$ & $27(47)$ \\
\hline care of patients with highly contagious diseases & 92 & $66(72)$ & $26(28)$ & $10(38)$ & $16(62)$ \\
\hline disposal of sharp contaminated instruments & 92 & $32(35)$ & $70(76)$ & $18(26)$ & $52(74)$ \\
\hline detection of /assistance during medical emergency incl. CPR & 92 & $86(93)$ & $8(9)$ & $5(63)$ & $3(38)$ \\
\hline firefighting & 92 & $91(99)$ & $1(1)$ & $0(0)$ & $1(100)$ \\
\hline
\end{tabular}

*note: 12 students only stated to have provided general nursing leaving all other questions unanswered.

\section{Discussion}

Health care workers are exposed to numerous potential hazards [5, 12, 28-36]. This does also apply for nonnursing students during nursing internship justifying our short-term educational intervention. Our results indicate acceptable performance levels for all learning objectives. Detection of effectiveness however is limited to selfreported outcomes of students. Since other events of internships like observed near misses in patient care are discussed during risk management lectures during the following semester, absence of severe sentinel events like needle stick injuries or second victim incidents seems credible. Some students rating training at nursing facilities as "fair" or better (German school grade 1-4) also stated that they did not receive any initial training at all. This could be most likely explained by reduced need for training due to prior professional experience (e.g. previous training as physician assistant) in some of the students but could also possibly refer to lack of situational awareness.

Since students are free to choose any nursing facility in Germany or comparable to German nursing standards, assessment of students' perceptions can be regarded as representative and evaluation of self-effectiveness can be regarded reasonable under the given circumstances. Quantification of risks for rare events like assistance during CPR or firefighting on a ward seemed to be adequate since these rare events occurred in this comparably small group of students with expected frequencies.

It should be assumed that deficits in initial training during nursing internships will also affect students in other educational settings such as nursing internships for high-school students or future medical students. To our knowledge there is no other preventive educational intervention like "Survival-Day" in any high-school or medical school in Germany.

\section{Conclusion}

We implemented a short-term intervention that was widely accepted and regarded more helpful by non-nursing BHCE students preparing for their tasks at nursing internship than their received initial training at nursing facilities.

One fourth of all BHCE students reported inadequate initial training at nursing facilities in general. Also more than half of all students were exposed to hazardous activities without preliminary safety training at nursing facilities supporting our primary hypothesis of inadequate initial training of nursing interns. This justifies the need of our curricular safety training Survival-Day in order ensure necessary safety training to keep nonnursing students as well as patients free from avoidable harm that otherwise could be caused.

As long as mandatory safety trainings for all non-nursing interns are not implemented at nursing facilities, educational institutions, sending students to nursing internships should implement short-term educational interventions like the Survival-Day @ Wiesbaden Business School to ensure minimum standards of occupational and patient safety during nursing internships.

\section{Abbreviations}

BHCE: Bachelor Health Care Economics (Bachelor of Science); BLS: basic life support; CPR: cardiopulmonary resuscitation; ERC: European Resuscitation Council

\section{Acknowledgements}

We acknowledge support from the German Research Foundation (DFG) and the Open Access Publication Funds of Charité - Universitätsmedizin Berlin.

The authors thank all participating instructors who participated in this study and the foundation Gesundheitsstadt Wiesbaden for donation of one CPR manikin prior to the start of this survey.

\section{Authors' contributions}

RS and THS conceived the study. RS, THS, AP and MR collected data and provided the first draft. All authors read and approved the manuscript.

\section{Funding}

Apart from the support from the foundation Gesundheitsstadt Wiesbaden, this research received no specific grant from any funding agency in the public, commercial, or not-for-profit sectors.

Availability of data and materials

The dataset is set up in the German language and therefore not suitable for international use. Interested researchers are encouraged to contact the authors for the provision of the used questionnaire or data. 


\section{Ethics approval and consent to participate}

Because of the research design, the need for a formal vote was waived after consultation of the Ethics Committee. To ensure data protection all data were collected without any demographic information allowing identification of participants. All participants gave their consent to use of data for this study.

\section{Consent for publication}

All participants were informed about the study and gave their consent to publication of survey data.

\section{Competing interests}

The authors declare that they have no competing interests.

\section{Author details}

'Wiesbaden Business School, RheinMain University of Applied Sciences, Bleichstraße 44, 65183 Wiesbaden, Germany. ${ }^{2}$ St. Josefs-Hospital Wiesbaden $\mathrm{GmbH}$, Quality Management, Beethovenstraße 20, 65189 Wiesbaden, Germany. ${ }^{3}$ University of Applied Science Mannheim, Professor of Social Law, Straßburger Ring 45, 68229 Mannheim, Germany. ${ }^{4}$ Department of Internal Medicine, Infectious Diseases and Respiratory Medicine, Charité Universitätsmedizin Berlin, corporate member of Freie Universität Berlin, Humboldt-Universität zu Berlin, and Berlin Institute of Health, Charitéplatz 1 , 10117 Berlin, Germany.

Received: 23 July 2019 Accepted: 22 November 2019

Published online: 04 December 2019

\section{References}

1. Appel P, Schuler M, Vogel H, Oezelsel A, Faller H. Short Questionnaire for Workplace Analysis (KFZA): factorial validation in physicians and nurses working in hospital settings. J Occup Med Toxicol. 2017;12:11. https://doi. org/10.1186/s12995-017-0157-6.

2. Bauer J, Groneberg DA. Physicians' working conditions in hospitals from the students' perspective (iCEPT-Study)-results of a web-based survey. J Occup Med Toxicol. 2016;11:5. https://doi.org/10.1186/s12995-016-0094-9.

3. Brutting M, Hermanns I, Nienhaus A, Ellegast R. Musculoskeletal stress during pushing and pulling hospital beds and wheelchairs. Zentralbl Arbeitsmed Arbeitsschutz Ergon. 2017;67:64-77. https://doi.org/10.1007/ s40664-016-0150-4

4. Kordsmeyer AC, Harth V, Mache S. Supportive strategies for pregnant women at the workplace. Zentralbl Arbeitsmed Arbeitsschutz Ergon. 2018; 68:113-7. https://doi.org/10.1007/s40664-017-0232-y.

5. Richarz S. Psychological stress in risk assessment. Zentralbl Arbeitsmed Arbeitsschutz Ergon. 2018;68:334-7. https://doi.org/10.1007/s40664018-0290-9

6. Seys D, Wu AW, van Gerven E, Vleugels A, Euwema M, Panella M, et al Health care professionals as second victims after adverse events: systematic review. Eval Health Prof. 2013;36:135-62. https://doi.org/10.1177/ 0163278712458918

7. Westermann C, Dulon M, Wendeler D, Nienhaus A. Hepatitis C among healthcare personnel: secondary data analyses of costs and trends for hepatitis C infections with occupational causes. J Occup Med Toxicol. 2016; 11:52. https://doi.org/10.1186/s12995-016-0142-5.

8. Wicker S, Nürnberger F, Schulze JB, Rabenau HF. Needlestick injuries among German medical students: time to take a different approach? Med Educ. 2008:42:742-5. https://doi.org/10.1111/j.1365-2923.2008.03119.x.

9. Exner M, Kramer A. Historische Entwicklung und aktuelle Anforderungen an die ärztliche Aus-, Fort- und Weiterbildung in der Hygiene und Infektionsprävention. Bundesgesundheitsblatt Gesundheitsforschung Gesundheitsschutz. 2012;55:1465-73. https://doi. org/10.1007/s00103-012-1565-5.

10. Kaur R, Razee $H$, Seale $H$. Facilitators and barriers around teaching concepts of hand hygiene to undergraduate medical students. J Hosp Infect. 2014;88: 28-33. https://doi.org/10.1016/j.jhin.2014.06.006.

11. Marino M, Braun M, Groneberg DA, Bendels MHK. Importance of occupational medical precautions for professional foreign residency. Zentralbl Arbeitsmed Arbeitsschutz Ergon. 2018:68:41-4. https://doi.org/10. 1007/s40664-017-0251-8

12. Michaelis M, Hofmann FM, Stossel U, Hofmann F. Norovirus outbreaks and cooperation between occupational health physicians and hygiene personnel in hospitals. Results of a survey among congress participants. Zentralbl Arbeitsmed Arbeitsschutz Ergon. 2017;67:309-13. https://doi.org/ 10.1007/s40664-017-0206-0.

13. Quart J, Deutsch T, Carmienke S, Dopfmer S, Frese T. Willingness to commute among future physicians: a multicenter cross-sectional survey of German medical students. J Occup Med Toxicol. 2018;13:17. https://doi.org/ 10.1186/s12995-018-0200-2

14. Strametz R, Schneider TH, Pitz A, Raspe M. Risk analysis for students in nursing internships: systematic evaluation and treatment of work-related risks for students in health care economy and patients using scenario analysis based on ONR 49002-2. Zentralbl Arbeitsmed Arbeitsschutz Ergon. https://doi.org/10.1007/s40664-019-00362-w.

15. Westermann C, Wendeler D, Nienhaus A. Hepatitis C in healthcare personnel: secondary data analysis of therapies with direct-acting antiviral agents. J Occup Med Toxicol. 2018;13:16. https://doi.org/10.1186/s12995018-0197-6.

16. Khabour OF, Al Ali KH, Mahallawi WH. Occupational infection and needle stick injury among clinical laboratory workers in Al-Madinah city, Saudi Arabia. J Occup Med Toxicol. 2018;13:15. https://doi.org/10.1186/s12995018-0198-5

17. Cheng S, Tollefson D, He G, Li Y, Guo H, Chai S, et al. Evaluating a framework for tuberculosis screening among healthcare workers in clinical settings, Inner Mongolia, China. J Occup Med Toxicol. 2018;13:11. https:// doi.org/10.1186/s12995-018-0192-y.

18. Schoffel N, Bendels MHK, Volante G, Groneberg DA. The human rotavirus infection. A review of the literature. Zentralbl Arbeitsmed Arbeitsschutz Ergon. 2017;67:321-3. https://doi.org/10.1007/s40664-017-0241-x.

19. Schoffel N, Braun M, Bendels MHK, Bruggmann D, Groneberg DA. Human hantavirus infections. A review of the literature. Zentralbl Arbeitsmed Arbeitsschutz Ergon. 2018:68:94-7. https://doi.org/10.1007/s40664-017-0223-z.

20. Schoffel N, Braun M, Bendels MHK, Groneberg DA. Legionellosis. The human infection with legionella. Zentralbl Arbeitsmed Arbeitsschutz Ergon. 2018;68: 341-5. https://doi.org/10.1007/s40664-017-0247-4.

21. Schoffel N, Braun M, Volante G, Klingelhofer D, Groneberg DA. The human infection with Listeria (listeriosis). A review of the literature. Zentralbl Arbeitsmed Arbeitsschutz Ergon. 2018:68:161-3. https://doi.org/10.1007/ s40664-017-0243-8.

22. Schoffel N, Klingelhofer D, Braun M, Bendels MHK, Groneberg DA. Catscratch disease. Zentralbl Arbeitsmed Arbeitsschutz Ergon. 2018;68:211-3. https://doi.org/10.1007/s40664-017-0224-y.

23. Schoffel N, Klingelhofer D, Braun M, Bruggmann D, Groneberg DA. Hand, foot and mouth disease. A review of the literature. Zentralbl Arbeitsmed Arbeitsschutz Ergon. 2018;68:91-3. https://doi.org/10.1007/s40664-017-0222-0.

24. Schoffel N, Klingelhofer D, Braun M, Groneberg DA. Shigellosis-infection with human pathogenic Shigella. Review of the literature. Zentralbl Arbeitsmed Arbeitsschutz Ergon. 2018;68:33-6. https://doi.org/10.1007/ s40664-017-0240-y.

25. Nolan JP, Soar J, Zideman DA, Biarent D, Bossaert LL, Deakin C, et al. European resuscitation council guidelines for resuscitation 2010 section 1. Executive summary. Resuscitation. 2010;81:1219-76. https://doi.org/10.1016/ j.resuscitation.2010.08.021.

26. Pande S, Pande S, Parate V, Pande S, Sukhsohale N. Evaluation of retention of knowledge and skills imparted to first-year medical students through basic life support training. Adv Physiol Educ. 2014;38:42-5. https://doi.org/ 10.1152/advan.00102.2013.

27. Mahling M, Münch A, Schenk S, Volkert S, Rein A, Teichner U, et al. Basic life support is effectively taught in groups of three, five and eight medical students: a prospective, randomized study. BMC Med Educ. 2014;14:185. https://doi.org/10.1186/1472-6920-14-185

28. Juranic B, Rakosec Z, Jakab J, Miksic S, Vuletic S, Ivandic M, Blazevic I. Prevalence, habits and personal attitudes towards smoking among health care professionals. J Occup Med Toxicol. 2017;12:20. https://doi.org/10.1186/ s12995-017-0166-5.

29. Girbig M, Freiberg A, Deckert S, Druschke D, Kopkow C, Nienhaus A, Seidler A. Work-related exposures and disorders among physical therapists: experiences and beliefs of professional representatives assessed using a qualitative approach. J Occup Med Toxicol. 2017;12:2. https://doi.org/10. 1186/s12995-016-0147-0

30. Bruggmann D, Groneberg DA. An index to characterize female career promotion in academic medicine. J Occup Med Toxicol. 2017;12:18. https:// doi.org/10.1186/s12995-017-0164-7. 
31. Varnai A, Nienhaus A, Groneberg DA, Ohlendorf D. Posture of employees exemplified by a hospital canteen kitchen an objective task analysis. Zentralbl Arbeitsmed Arbeitsschutz Ergon. 2018;68:197-205. https://doi.org/ 10.1007/s40664-017-0238-5

32. Seidler A, Schmeisser G, Selbig M, Drews A, Hammer I, Liebe S, et al. Employing pregnant surgeons in the operating theatre. Zentralbl Arbeitsmed Arbeitsschutz Ergon. 2018;68:27-9. https://doi.org/10.1007/ s40664-017-0255-4.

33. Sammito S. Workplace health promotion. Effects of increased physical activity in prevention of diseases. Zentralbl Arbeitsmed Arbeitsschutz Ergon. 2018;68:357-66. https://doi.org/10.1007/s40664-018-0312-7.

34. Nubling M, Vomstein M, Haug A, Lincke HJ. Are reference data from the COPSOQ database suitable for a JEM on psychosocial factors at work? Zentralbl Arbeitsmed Arbeitsschutz Ergon. 2017;67:151-4. https://doi.org/10. 1007/s40664-017-0182-4.

35. Lazarovici M. Human factors in medicine. Zentralbl Arbeitsmed Arbeitsschutz Ergon. 2017;67:124-37.

36. Eickmann $U$, Thullner I. Working with formaldehyde in the healthcare service. What are appropriate protective measures? Zentralbl Arbeitsmed Arbeitsschutz Ergon. 2017;67:22-31. https://doi.org/10. 1007/s40664-016-0145-1.

\section{Publisher's Note}

Springer Nature remains neutral with regard to jurisdictional claims in published maps and institutional affiliations.

Ready to submit your research? Choose BMC and benefit from:

- fast, convenient online submission

- thorough peer review by experienced researchers in your field

- rapid publication on acceptance

- support for research data, including large and complex data types

- gold Open Access which fosters wider collaboration and increased citations

- maximum visibility for your research: over $100 \mathrm{M}$ website views per year

At BMC, research is always in progress.

Learn more biomedcentral.com/submissions 